Revista de

Contabilidade e

Organizações

www.rco.usp.br
DOI: http://dx.doi.org/10.11606/issn.1982-6486.rco.2019.164412
Journal of

Accounting and

Organizations

\title{
The opportunistic approach of the Positive Accounting Theory (PAT) fails to explain choices made at OGX: An anomalous situation?
}

A abordagem oportunista da Teoria Positiva da Contabilidade (PAT) falha ao explicar as escolhas feitas na OGX: uma situação anômala?

\author{
Adolfo Henrique Coutinho e Silva ${ }^{\mathrm{a}}$, Moacir Sancovschi ${ }^{\mathrm{a}}$, Ariane Gabriela Chagas dos Santos ${ }^{\mathrm{b}}$ \\ ${ }^{a}$ Universidade Federal do Rio de Janeiro
}

"Pesquisadora independente

\section{Keywords}

Accounting choices.

Earnings management.

Positive accounting theory.

Efficient approach.

Case study.

\begin{abstract}
This paper has two objectives: (1) to demonstrate that the main accounting choices made by accountants and managers of OGX Company throughout its full business life cycle were not opportunistic, as often suggested by the hypothesis of Positive Accounting Theory; and (2) to demonstrate that these accounting choices may be better explained by the Theory of Corporate Scandals, by the Monitoring Hypothesis and by the Corporate Reputation Hypothesis. The research was conducted using a longitudinal case study approach, from 2006-2015, in order to identify visible accounting decisions in annual financial statements reports. It was found that the analyzed Company had the incentives to preform opportunistic accounting choices, such as the ones predicted by the PAT hypothesis and had also done through several situations in its business life cycle that could have influenced it to perform opportunistic accounting choices. However, there is no evidence that the Company ever made use of either opportunistic increasing-income accounting changes to impact their financial debt-covenants and bonus plan, or decreasing-income accounting to avoid government intervention, as suggested by the opportunistic approach of PAT hypothesis.
\end{abstract}

\section{Resumo}

Este artigo tem dois objetivos: (1) demonstrar que as principais escolhas contábeis feitas pelos contadores e gerentes da OGX Company ao longo de todo o ciclo de vida de seus negócios não foram oportunistas, como frequentemente sugerido pelas hipóteses da Teoria Positiva da Contabilidade; e (2) demonstrar que essas escolhas contábeis podem ser melhor explicadas pela Teoria dos Escândalos Corporativos, pela Hipótese do Monitoramento e pela Hipótese da Reputação Corporativa. A pesquisa foi conduzida usando um estudo de caso longitudinal, de 2006 a 2015, a fim de identificar decisões contábeis visíveis nos relatórios anuais das demonstrações financeiras. Verificou-se que a empresa analisada tinha incentivos para a realização de escolhas contábeis oportunistas, como as previstas pelas hipóteses da PAT, e também passou por diversas situações em seu ciclo de vida comercial que poderiam ter influenciado a realização de escolhas contábeis oportunistas. No entanto, não há evidências de que a Companhia tenha feito uso de alterações contábeis oportunistas para aumento do resultado para impactar seus covenants de divida financeira e plano de bonus dos administradores, ou redução do resultado para evitar a intervenção do governo, conforme sugerido pela abordagem oportunista da PAT.

\section{Practical implications}

This study extends the literature by providing additional evidence that companies do not always perform opportunistic accounting choices in certain contexts, even when there are incentives to do so. 


\section{INTRODUCTION}

Managers tend to favor the status quo in accounting methods and also resist changes in accounting standards induced from authorities for three main reasons: First, accounting changes may beget a qualified audit opinion and attract unfavorable publicity. Second, they require more work, staff training, the acquisition and implementation of new softwares, extra audit fees, as well as the time and effort to explain and justify such changes to skeptical directors and investors. Third, accounting changes could affect the welfare of all agents involved and may be received with some suspicion by non-managerial agents (Sunder 1997, p. 60). Recently, Nobes and Stadler (2014) provided some evidence that supports these assertions.

However, previous studies (for example, Ronen and Yaari, 2010) have documented that managers using the flexibility allowed by accounting standards may perform opportunistic voluntary changes in accounting practices in order to impact external contracts or maximize their own compensations. Notably, since the 1980s, most studies have used the PAT hypothesis to explain the opportunistic accounting choices, disregarding the possibility that the assumptions of this theory can also be used to explain efficient accounting choices.

Recently, studies of accounting choices based on the PAT Hypothesis have received severe criticism on the methodologies employed. Ball (2013), for example, mentioned that it seems strange that the magnitude of manipulations usually identified by academic researchers may be relevant, and yet, often ignored by the business press and the professionals who are supposed to spot such manipulations, such as external auditors and financial analysts. He recommended that research projects should be more detailed, avoiding delegating the evaluations of the existence of opportunistic accounting choices to statistical models that don't take into account the choices that would have been made in the absence of accounting manipulation.

Fields et al. (2001, p. 255) also concluded that 'research in the 1990's made limited progress in expanding our understanding of accounting choice because of limitations in research design and a focus on replication rather than extension of current knowledge'. According to these authors, one reason for the lack of progress is that researchers generally focus on refining knowledge of specific accounting choices or on narrow problems that accounting choices are presumed to address. Consistent with the acknowledged complexity of the task, there have been few attempts to take an integrated perspective (i.e., multiple goals) on accounting choices' (Fields et al. 2001, p. 258). To address this issue Fields et al. (2001, p. 301) suggested that researchers should make both small sample studies and perform studies that would encourage their expertise as accountants, notwithstanding the limitations and costs of these research designs.

In this context, our paper has two objectives: The first is to demonstrate that the main accounting choices made by accountants and managers of OGX Company throughout its full business life cycle were not opportunistic, as often suggested by the Positive Accounting Theory hypothesis (PAT hypothesis, hereafter). The second objective is to demonstrate that these accounting choices may be better explained by the Theory of Corporate Scandals' Hypothesis, the Monitoring Hypothesis and the Corporate Reputation Hypothesis.

This research is relevant because it (a) studies the major accounting changes made by managers and accountants throughout the life cycle of a single company; (b) uses, for this purpose, information presented in that company's financial statements rather than estimates obtained through the application of methods that Watts and Zimmerman (1990), Fields et al. (2001) and Ball (2013) found problematic; and (c) examines events that Taleb (2007) calls "silent", as they are forgotten, ignored or discarded, to show that accounting changes do not always follow the patterns predicted in the assumptions usually stated in the standard version of positive accounting theory.

The following section discusses the literature on accounting choices with emphasis on the PAT hypothesis. The third section presents the methodology of the study, containing the criteria used in choosing the company and how the data was collected and analyzed. The fourth section makes up the presentation of the analyzed company and its accounting choice information. In the fifth section, we carry out the analysis of the results. And finally, in the last section, section sixth, we present our final remarks.

\section{THEORETICAL BACKGROUND}

Positive Accounting Theory (PAT), proposed by Ross Watts and Jerold Zimmerman, attempts to explain and predict the choices of accounting practices made by managers under different circumstances. 
Although the accounting standards, for sake of reporting efficiency allows managers some flexibility (ex ante) to choose from a set of available accounting practices, it also opens up the possibility of opportunistic behavior ex post. Thus, managers may choose accounting practices for their own best interests and maximize their utility, thereby reducing contract efficiency (Scott 2009, p. 285). According to Watts and Zimmerman (1986 and 1990), this situation (Opportunistic Approach) arises from information asymmetry, a problem that exists in the relationship between shareholders (principal) and managers or controlling shareholders (rational agents), as suggested by the Agency Theory.

Despite managers' presumed tendency of choosing accounting methods that suit their self-interests and ensure their personal welfare, their choices are constrained by the options available in the GAAP (Sunder 1997). Research under the Positive Accounting Theory has examined three aspects of accounting choices: (1) the motivation to make them, (2) the time they are made, and (3) how they are made.

Regarding the motivation to make the choices, three hypotheses were proposed and tested. The Bonus Plan Hypothesis, the Debt Covenant Hypothesis (or Debt-to-Equity Hypothesis); and the Political Costs Hypothesis (Watts and Zimmerman, 1986).

According to these hypothesis, managers choose less conservative accounting procedures (Debt-Equity Hypothesis), or more conservative accounting procedures (Political Costs Hypothesis) to create benefits for the firm, but they could also adopt a less conservative and less volatile accounting procedure (Bonus Plan Hypothesis) to their own benefit (against the firm's interests) (Stolowy \& Breton, 2003).

Regarding when accounting choices are made, research has focused on critical events in the life of companies. In general, these studies suggest that companies are more likely to carry out accounting choices prior to the Initial Public Offering (IPO), before a bankruptcy, severe financial distress, or when they have difficulties meeting the analysts' and investors' expectations.

Regarding how changes are made, studies seek to capture their effects based on different constructs and measures. The three main approaches used consist of (a) the construction of abstract variables that measure the level of discretionary and non-discretionary accruals arising from the application of the accrual basis of accounting methods employed by the companies, (b) the analysis of declared accounting policies in the companies` financial statements; or (c) the analysis of voluntary and mandatory changes in accounting practices.

Although empirical studies of earnings management focus on only one or two instruments at a time, for Sunder (1997), managers use many instruments to manage income at the same time. Sunder (1997, p. 76) emphasizes that the initial choices and the changes in accounting principles are observable to outsiders while the adjusting on accounting estimates (the allowance for bad debt, the economic life for depreciation, and the discount rate for pension obligations, for example) gives more flexibility to management because an outside observer cannot readily detect when such discretion is used with the intention to manage income.

Of course, the accruals measures are more comprehensive in capturing the effects of accounting choices, for the effects of changes in accounting estimates, for example, but have a natural limitation in identifying the direct effects of opportunistic changing in accounting policies. On the other hand, the analysis of accounting changes alone, although more objective, does not capture all existing effects. Notably, this trade-off in the form of operationalization of the study is crucial to explain the results observed in the previous studies. Usually, the analysis of changes in accounting policies is predominant in qualitative studies, where it allows a better observation of the phenomenon. It is also noteworthy that the analysis of accounting choices made by managers depend on the accounting framework used, that is, the accounting choices are made within the available alternatives in the accounting standards adopted in the country.

The accounting choices studies in the oil and gas industry also support the PAT predictions (Johnson, and Ramanan, 1988, Chen and Lee, 1995, and Pincus et al., 2002). The accounting research in this industry is concentrated on the choice of accounting method in oil exploration and drilling expenses treatment (Full cost method versus Successful efforts method). The accounting choice studies in the oil and gas industry was usually related to the Political Cost Hypothesis (Fern et al., 1994, Hall and Stammerjohan, 1997 and Han and Wang, 1998).

Despite several studies supporting the opportunistic PAT hypothesis, Malmquist (1990) argues that the results are consistent with the choice of accounting method in the oil and gas industry being dominated by the principles of efficient contracting, and inconsistent with the opportunistic behavior of managers. 
According to Scott (2009), the PAT hypotheses can also be interpreted from an efficient contracting perspective. Thus, the efficient and opportunistic approach of PAT Hypothesis could also make similar predictions. It can be difficult to tell whether the firms' observed accounting policy choices are driven by opportunism or efficiency. For Scott (2009, p. 297) while managers ' concerns about accounting policies and standards may be driven by opportunism or by efficient contracting, there is significant evidence in favor of the efficient contracting version according to PAT. This suggests that firms are able to align managers' interests with those of the shareholders'.

For Belkaoui (2004, p. 447) "management is knowing how to choose the optimal accounting procedures for a given purpose". The central problem of the positive approach rests in determining what factors are likely to affect the optimum choice, guided by the assumption of agency and contracting cost theories.

It is worth emphasizing that a few prior studies (see, for example, Christie and Zimmerman 1994; Malmquist, 1990) point out that a number of efficient accounting choices may have been misinterpreted as opportunistic. This may occur due to the difficulty in determining whether the objective behind the managers' accounting choices intend to maximize firm value or just serve their own interests. As shown by Christie and Zimmerman (1994), most studies of accounting policy choice are assumed to be the result of opportunistic behavior, which may be considered an ordinary bias in this accounting literature.

It is important to point out that, despite the acknowledged importance of the Positive Accounting Theory hypotheses and the efforts made to test them, some alternative hypotheses that are less well known and cited, though not less important, have been proposed and tested.

The hypothesis of The Theory of Corporate Scandals submitted by Coffee Jr (2005) states:

“[...] that different kinds of scandals characterize different systems of corporate governance. In particular, dispersed ownership systems of governance are prone to the forms of earnings management that erupted in the United States, whereas concentrated ownership systems (as are found in Europe) are much less vulnerable. Instead, the characteristic scandal in concentrated ownership economics is the appropriation of private benefits of control. Here, Parmalat is the representative scandal, just as Enron and WorldCom are the iconic examples of fraud in dispersed ownership regimes".

According to Coffee Jr. (2005), the financial misconduct also has implications on both the utility of gatekeepers both as reputational intermediaries and on designing of legal controls to protect public shareholders.

Bos and Donker (2004) submitted the Monitoring Hypothesis, which states that institutional monitoring, like an external control from (a) large shareholders, (b) institutional shareholders, and (c) financial authorities; and (d) internal control from a supervisory board are important to reduce the agency problems and avoid opportunistic accounting choices.

According to Monitoring Hypothesis, large outside shareholders and financial authorities will monitor voluntary accounting changes more effectively than small shareholders and will restrict managers' opportunistic behavioron increasing reported net income.

Stolowy and Breton (2003, p. 42) affirm that there are some potential losses when companies manipulate their accounts: (a) Managers could lose their jobs and their own reputation; (b) shareholders could lose their confidence in the market; (c) Potential bondholders could transfer wealth to the actual shareholders; and (d) Government could increase the tax collection.

As good corporate reputations are critical due to their potential for value creation (Roberts and Dowling 2002), managers could avoid performing opportunistic accounting changes to preserve their reputation and image (Corporate Reputation Hypothesis). According to Chun (2005), corporate reputation affects the way in which various stakeholders behave towards an organization and a favorable reputation encourages shareholders to invest in a company, and for this reason, a CEO sees corporate reputation as a valuable intangible asset (accounting perspective).

\section{RESEARCH METHOD}

Following Armenic (1992) and Jorissen and Otley (2010), we selected a critical and paradigmatic case study approach (see Cooper \& Morgan, 2008 and Ryan et al., 2002). 
The company selected for this analysis is formally known as 'Óleo e Gás Participações S.A. (OGPar)' and until December 6, 2013 its name was 'OGX Petróleo e Gás Participacoes S.A.' (Brazilian’ SEC code: 20168), which will be referred, in this paper, as 'The Company'.

The Company had specific characteristics, like operating in a regulated environment - oil and gas industry, having a short life cycle, going bankrupt, having political engagements and lobby activities, and having international operations.

The choice of company was based on three factors: First, the full business life cycle could be observed, and the company went through all stages of its life cycle in a short period, while other companies generally take more time. The company went through growth and decline stages in its business life cycle in a relatively short period of time. It started its pre-operational phase and entered the decline stage (backruptcy protection) in a span of just ten years. Second, the company stood out in its economic importance in the oil and gas industry and had a significant participation in the Brazilian stock market (4.52\% in the Ibovespa index, in December 2013). Third, the company is listed, so it publicly discloses all its annual reports on the Brazilian Securities and Exchange Commission website.

In this study, we used hand-collected data from the documents available on the Comissão de Valores Mobiliários (CVM - Brazilian Securities and Exchange Commission) website (www.cvm.gov.br) and The Company's Website available until August 2015. We analyzed several documents: (1) relevant facts reports, (2) communication to the market reports, (3) the auditors' reports, and (4) published financial statements (including the footnotes) from birth, in April 2006, until the first semester of 2015 (ten years), the reference date of the last financial statement available. Thus, nine years of annual financial statements (longitudinal study) of visible accounting choices (Amernic, 1992) were analyzed in order to understand the evolution of the company's accounting practice over its business life cycle, with emphasis on the analysis of the voluntary accounting changes carried out.

Although we use several sources of information (within-method triangulation), the footnotes of the annual financial statements are the main focus of our analysis. The analysis of the information published in the annual financial statements and other official sources is justified because of the accessibility of the data as well as a greater objectivity and impartiality in collecting the information. The use of interviews or questionnaires have uncertain value in this study, given the turnover of top executives and key employees during the reporting period not to mention possible restrictions to disclose confidential or relevant information related to the Company.

We adopted a simple protocol to ensure its internal validity (Eisenhardt, 1989). The first step was to identify voluntary accounting practices changes (phenomenon under investigation). The second step was to verify the existence of incentives and situations where the literature review indicatedwere favorable for the realization of accounting practices changes (hypothetical explanation of the phenomenon). The third step was to analyze if there was evidence proving the relationship between these voluntary changes and a trigger situation. This process was repeated individually by each author, and divergences in the results were analyzed and discussed.

The main focus of the analysis is the 'visible accounting decisions' (Armenic, 1992), especially discretionary accounting policy changes as it mean selecting a different option from the previous year. (Nobes, 2014).

The qualitative analysis of changes in accounting practices of the Company over time can provide a better understanding of (1) a significant effect resulting from the use of different accounting methods; (2) a significant effect on replacing an accounting method for another; or (3) a difference of opinion among auditors and users regarding the acceptability of one or more accounting methods used in the reports (Hendriksen and Breda, 1991).

\section{THE CASE STUDY DATA}

\subsection{Business life cycle evolution of the Company}

The Company analyzed was created on April 10, 2006, with headquarters in Rio de Janeiro, and controlling other domestic and foreign companies, operating in the exploration and production of oil and natural gas. On July 19, 2006 the Company was listed in The Brazilian Securities Exchange Commission.

In June 2008, the Company raised R\$ 6.7 billion in a public offering (Initial Public Offering - IPO) on the stock market (Bovespa), the biggest one ever held in Brazil by that time, and started to hire professionals, equipment and services for the exploration campaign and to initiate prospection and interpretation of seismic data in exploration blocks. 
In 2009, the Company announced the first drilling at the Campos Basin well, considered the most prolific basin in Brazil, in addition to acquiring a 70\% interest in seven exploration blocks in The Parnaíba Basin. It announced its first hydrocarbon discoveries in the basins of Campos and Santos, ending the year with a fund's portfolio estimated at 6.7 billion barrels for the company. It is worth pointing out that still in 2009, the Company announced their production targets for the years 2011, 2015 and 2019, which estimated an average daily production of, respectively, 20,000, 730,000 and 1.38 million barrels of oil equivalent.

At the beginning of 2010, the company was included in the Ibovespa index and already showed a more complex corporate structure.

In 2012 problems started. The beginning was good, with the start of oil production in 'Waimea', in the Campos Basin, the discovery of the presalt layer in shallow waters of the Santos Basin and the delivery of the first oil cargo to Shell.

However, in mid-2012, the Company's shares plummeted on the stock Exchange, which began to contaminate the other companies in the group. With the return of exploration blocks to ANP (National Petroleum Agency), such as the VMM-26 block, where an environmental area restriction prevented exploitation. Exploration blocks BM-S-29 and BM-ES-38, in which the company had 100\% and 50\%, respectively, were also returned due to lack of results. The company announced the new issuance of debt securities in the Market totaling US\$ 1.063 billion, as the production in Tubarão Azul Field, had not reached the previously estimated target, recording the biggest loss in its history. In July 2012, the main subsidiary of the Company (OGX E\&P) was converted from a private limited liability company to a public corporation, causing some accounting changes that will be detailed in the next section.

2013 began full of promises from the President of the Company, even though many of these promises would not be kept. However, the Company started the year celebrating the first oil extraction from Tubarão Azul field and making the third connection production well field in the Campo Basin as well as beginning the commercial production of natural gas in the Parnaíba Basin in the state of Maranhão.

In May of 2013, an agreement signed with Petronas for the sale of $40 \%$ of the stake in blocks of concession BM-C-39 and BM-C-40 in the Campos Basin came to an end, but before transferring resources to Petronas, a more concrete definition of the Company's restructuring was being demanded. On November 19, 2013, the Company was notified of the termination of the contract.

Due to the failure in negotiating their debts and accumulated losses, the Company filed for bankruptcy protection of four companies of the group in order to preserve its continuity and protect its business. The company, which once had a market value of $\mathrm{R} \$ 22.27$ per share at its peak (October 10, 2010), closed 2013 with a price of R $\$ 0.24$ per share. On November 26, 2013, the price came to a low of R\$ 0.14 per share shown in the Graph 1.

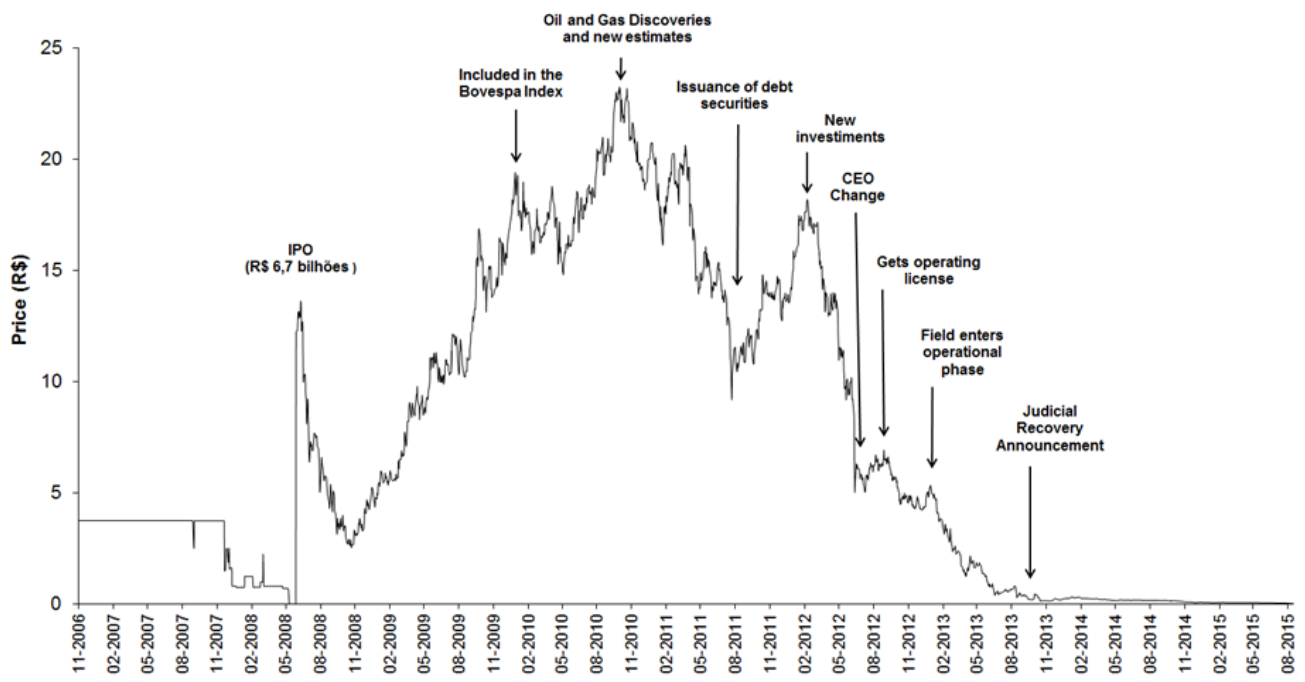

Graph 1. Evolution of company's stock prices of November, 2006 to August, 2015 Source: Stock prices available on the Yahoo Finance site, September, 2015. 
The Company filed for bankruptcy protection (debts reorganization in Court), which consisted of a proposed 'reverse merger' (parent company incorporated by the subsidiary company), which resulted in a new public company. The purpose of the merger, as declared (footnote page 22, in Financial Statement 2013), was to level all stakeholders within the same company and give them access to the market capital with the possibility of negotiating their shares and monetize them as they saw fit. However, for the Company to maintain the continuity of its operations, it depended on the approval and implementation of its filing request.

The following information details the main aspects related to the company's incentives to make accounting choices, as suggested by the literature.

\section{About the Company's Debt Covenants}

The Company had some financial covenants in their loans and finances such as limits on new indebtedness, payments to shareholders, sale or encumbrance of assets. According to the Company, the main financial parameter to be observed for new indebtedness or payments to shareholders was net debt, whose value should exceed at least one of the following tests: (a) not being greater than the equivalent of US\$ 4 billion; or (b) not resulting in a net debt to EBITDA ratio of more than 3.5 times.

The failure to comply with such covenants could result in early maturity of the two senior unsecured notes issued in the international market. The first senior unsecured notes were issued on June 3, 2011 in the amount of US\$ 2.563 billion, with the maturity in 2018 and semi-annual interest at the rate of $8.5 \%$ per year. The second was issued on March 30, 2012 in the amount of US\$ 1.063 billion, with the maturity in 2022 and interest rate of $8.375 \%$ per year). In 2013, the Company incurred in financial covenant default and reclassified their notes to current liabilities.

\section{About the Company's Stock Options Plan}

In order to incentive the company's key executives and motivate them to achieve long-term results, the Company awarded options to all directors and key managers to purchase shares. The Company had two sharebased payment plans: (a) the option plan granted by the Company (Parent Company) and (b) the option plan granted by the controlling shareholder.

The members of the Board of Directors, officers and key employees were allowed to jointly acquire $1 \%$ and $4.6 \%$ of the company's shares and controlling shareholder, respectively. According to the Company, all transactions involving share-based payments were classified as being equity settled, and the Company did not have stock purchase options that could be settled in cash. (Annual Report 2012, page 58)

The fair value of the stock options was calculated by using the Black \& Scholes option pricing model, individually, for each beneficiary as of the grant date, and recognized on a pro rata basis over the vesting period. Upon exercise of the stock options, the respective fair values accumulated in the capital reserve would be reclassified to earnings reserve, while non-fulfillment of the vesting terms and conditions, which in both cases involved the grantee remaining at the Company for a pre-defined vesting period, the expense previously recognized associated with the future vesting period would be cancelled through a credit to income and charge to the capital reserve. (Annual Report 2012, page 60)

Some stock purchase option plans featured guarantee clauses whereby the Company ensured the beneficiary would have a minimum gain on the final anniversary of the contract [Guaranteed minimum payment]. In the event the grantee dids not obtain this minimum gain through the options exercised, the Company should complement the difference through a cash disbursement. (Annual Report 2012, page 61)

The Stock Options Plans were not associated with accounting performance (metrics like net income, for example), s therefore, managers did not have any direct incentive to influence the Company's accounting practices.

\section{About the Company's Merger and Acquisitions}

On May 31, 2012, the Company’s wholy-owned subsidiary OGX Campos Petróleo e Gás S.A. was merged upstream into OGX Petróleo e Gás S.A. The net assets incorporated amount was R \$1,476,692 thousand. These business combinations called for the assets and liabilities of the acquiree not to be re-measured at their fair value, but instead recognized at the acquirer at same amounts as they were recorded at the acquiree (Company's Annual Report 2012). 


\section{About the Company's Auditors Change}

In the second year of operation, the company chose to change the local audit firm (Acal Consultoria e Auditoria S/S) and hired a larger international firm (KPMG Independent Auditors, 2007-2011). This seemed a natural procedure for companies that had grown and, consequently, started to seek greater credibility in the quality of financial information disclosed. Notably, the change of audit firm occurred in the same year (2007) the company changed its corporate name.

In 2012, the Company replaced the audit firm, hiring Ernst \& Young Independent Auditors SS, a mandatory rotation procedure required by standard issued by the Brazilian' Securities and Exchange Commission (Instruction CVM No 308/99).

The auditors' opinions of 2010, 2011 and 2012 included a pattern emphasis on a Brazilian context. The accounting invested in subsidiaries in separate financial statements, prepared in accordance with local accounting practices, applied equity method while international accounting standards (IFRS) required cost or fair value measurement. In 2013 and 2014 the auditors issued an unqualified audit report where they cast doubt on the Company's ability to continue as it became going concern.

On March 31, 2015 the Board of Directors approved of hiring KPMG Independent Auditors (KPMG) to audit the financial statements for the fiscal year 2015, replacing PricewaterhouseCoopers (PwC). According to the Company, the change of auditor took place for commercial reasons.

\subsection{Description and analysis of the company's accounting practices changes}

During the Company's business life cycle, we can observe that it did not distribute any dividends and that in the years 2012 and 2013, net losses grew significantly due to the low operating costs.

Despite the group's parent company presenting itself as being in the 'operational phase', notably several investments activities of the economic group remained in the pre-operational phase, that is, in the exploration stage. Intangible Assets basically referred to the costs incurred during the exploration phase under development. Intangible Assets showed significant growth in 2010 and 2011, while they showed a significant low in the years 2012 and 2013. In general, the amounts reported reflect the operational and economic issues discussed in the previous session.

During the Company's business life cycle, we could identify a number of mandatory and voluntary accounting practices changes. Table 1 shows the summary of the main Company's business events and accounting practices changes.

In its first part of the business life cycle (2006 and 2007 years), the Company's accounting practices were quite simple. In this period, the Company performed a corporate restructuring (incorporation, and spin-off and merger) and issued new type of shares and changed the equity composition without making any change in its accounting practices.

In the years 2008-2010 (growth stage), the Company presented a significant growth in its operations and became an important company in the Brazilian economic scenario with a relative strong participation in the capital market. 
Table 1. Main Company's' Accounting Change

\begin{tabular}{|c|c|c|c|}
\hline Year & Main Events & $\begin{array}{l}\text { Accounting Change } \\
\left.\text { (Category }^{\mathrm{a}} \text { / Type }{ }^{\mathrm{b}}\right)\end{array}$ & Effects on accounting metrics \\
\hline 2006 & $\begin{array}{l}\text { Start of operation and Brazilian' } \\
\text { SEC listing }\end{array}$ & --- & --- \\
\hline 2007 & $\begin{array}{l}\text { Corporate Restructuring } \\
\text { (merger and spin-off) }\end{array}$ & $--^{c}$ & -- \\
\hline 2008 & Initial Public Offering & $\begin{array}{l}\text { Mandatory / Recognition, } \\
\text { Measurement and Reclassification }\end{array}$ & $\begin{array}{l}\text { Balance Sheet Adjustments; } \\
\text { No net income effects disclosed }\end{array}$ \\
\hline 2009 & $\begin{array}{l}\text { Company will be part of the } \\
\text { portfolio of the IBrX and IBrX- } \\
50 \text { index; Beginning the GDR } \\
\text { Program (Level 1) }\end{array}$ & $\begin{array}{l}\text { Mandatory / Recognition, } \\
\text { Measurement and Reclassification }\end{array}$ & $\begin{array}{l}\text { Balance Sheet Adjustments; } \\
\text { No net income effects disclosed }\end{array}$ \\
\hline 2010 & $\begin{array}{l}\text { Company will be part of the } \\
\text { portfolio of the Ibovespa index; } \\
\text { Joins the Carbon Efficient Index; } \\
\text { IFRS full mandatory adoption }\end{array}$ & $\begin{array}{l}\text { Full IFRS adoption; } \\
\text { Voluntary / Recognition } \\
\text { (earlier adoption of IFRS 6) }\end{array}$ & $\begin{array}{l}\text { Balance Sheet Adjustments } \\
\text { No net income effects disclosed } \\
\text { from full IFRS adoption }{ }^{\text {g }} \\
\text { Income-increasing effects from } \\
\text { IFRS } 6 \text { adoption }\end{array}$ \\
\hline 2011 & $\begin{array}{l}\text { Issuance of debt securities abroad } \\
\text { totaling US\$ } 2.563 \text { billion; } \\
\text { Disclose of the Resource } \\
\text { Assessment Reports and new } \\
\text { Business Plan; } \\
\text { Controlling acquisition; } \\
\text { Mandatory Auditor Change }\end{array}$ & $\begin{array}{l}\text { Voluntary / Reclassi-fication; } \\
\text { Recognition } \\
\text { (Small Assets Write-downs) }\end{array}$ & $\begin{array}{l}\text { Balance Sheet and Cash Flow } \\
\text { Statement Adjustments; } \\
\text { No net income effects } \\
\text { Expenses of R } \$ 40,4 \text { million }\end{array}$ \\
\hline 2012 & $\begin{array}{l}\text { Company announces issuance of } \\
\text { debt securities abroad totaling } \\
\text { US } \$ 1.063 \text { billion; } \\
\text { Company announces new Chief } \\
\text { Executive Of-ficer; } \\
\text { Merger upstream } \\
\text { (OGX Campos to OGX Petróleo) }\end{array}$ & Voluntary / Reclassification & $\begin{array}{l}\text { Balance Sheet Adjustments } \\
\text { No net income effects (d) }\end{array}$ \\
\hline 2013 & $\begin{array}{l}\text { Debt Covenant violation; } \\
\text { Changes in the composition of its } \\
\text { Board of Directors; } \\
\text { Statement of sale of relevant } \\
\text { shareholding shares; } \\
\text { Judicial Recovery request }\end{array}$ & $\begin{array}{l}\text { Voluntary / Recognition } \\
\text { (Significant Assets Write-downs) }\end{array}$ & $\begin{array}{l}\text { Income-decreasing effects } \\
\text { (R\$ } 8,7 \text { billion of impairment } \\
\text { provisions) }\end{array}$ \\
\hline 2014 & $\begin{array}{l}\text { Loan-bridge of US\$ } 50,0 \text { billion } \\
\text { and additional loan of US } \$ 73,2 \\
\text { billions; } \\
\text { Offering assets in Colombia; } \\
\text { Approval of the Judicial Recovery } \\
\text { Plan }\end{array}$ & $--^{\mathrm{e}}$ & --- \\
\hline 2015 & $\begin{array}{l}\text { Changes in Board of Directors } \\
\text { composition; } \\
\text { Voluntary Auditors Change }\end{array}$ & $---^{f}$ & --- \\
\hline
\end{tabular}

Source: Research data.

Note: (a) Category: Mandatory or Voluntary. (b) Type: Recognition, Classification, or Measurement. (c) Mandatory accounting change from Transition-period to IFRS adoption not evaluated by the Company. (d) Merger upstream reduced the net income from R\$ $1,172,774$ to R\$ 1,185,876 (impact reduction of losses in R\$ 13,102). (e) The Company adopted IFRS 5 (Non-Current Assets Held for Sale and Discontinued Operations) for some assets. (f) Annual Report not available. (g) 2010 Financial Statement was prepared adopting IAS 8 (Accounting Policies, Changes in Accounting Estimates and Errors). The retrospective net income effects were income-decreasing by R\$ 89,797 in 2009. 
In the initial growth stage, the Company had several projects in pre-operational phase. In this period, it is observed that the accounting practices recorded the capitalized exploration expenses without carrying out the depreciation of the fixed assets considering the expectation of future benefits that would be achieved when the company started its operational phase. As the projects started their operational phase so did depreciation, as required by IAS 28 (Fixed Assets). Despite the Company`s having several projects in pre-operational phase in its subsidiary companies, it was considered to be in its operational phase as it was a holding company.

In 2008 and 2009, the Company carried out the Initial Public Offering (2008), took part of IBrX and IBrX 50 index (2009), and started the GDR Program - level 1 (2009) but it did not implement any kind of voluntary accounting changes.

In these years, the firm just implemented mandatory accounting changes required by the adoption of international accounting standards (IFRS), issued by the International Accounting Standards Board (IASB), as required by Law No 11,638/07. In the IFRS transition period (2008 and 2009 financial statements), the Company conducted some reclassifications of balance sheet accounts such as (a) transfer of pre-operating expenses from Deferred Assets to Intangible Assets; (b) reclassification of the transactions cost incurred in the private share offering; and (c) transfer of expenses with drilling wells from Deferred Assets to Intangible Assets. These adjustments did not produce any significant effects on net income.

In 2010 and 2011, we observed a considerable company growth. In 2010, the company was listed in Ibovespa Index (the main stock Market index in Brazil) and disclosed several 'Relevant Facts' (equivalent to Current Reports in USA) about their operations, like announcing oil discoveries, estimates of production level and overall optimistic information. In 2011, the Company issued new significant debt securities, made a business combination (assets acquisitions), disclosed a new Business Plan, made a mandatory auditor change and continued disclosing good news about their operations and the potential of its portfolio. In 2011, we could also observe a high volatility in the Company's share price in the stock Market.

About the accounting practices, in 2010, the Company made a voluntary adoption of the IFRS 6 (Exploration for an Evaluation of Mineral Resources) in addition to the full IFRS adoption. Despite this new standard causing a positive effect on the net income, the Company presented net losses of R\$135.5 million in its 2010 Statement Income. Although IFRS 6 was not mandatory in Brazil, this new standard had already been adopted by major international companies in the oil and gas industry. Probably, this new benchmark standard in the oil and gas industry could have been an important factor influencing the Company`s decision to adopt this standard earlier, which allowed better comparability of financial statements.

The following information was taken from the Company's footnote.

\section{'3.2 Change in accounting practice}

Minimum Working Program

The Company changed its accounting practice for the commitments to ANP's Minimum Exploration Program, in the amount R\$ 618,532 on June 30, 2010, aiming at adaptation to best market practices for the petroleum and natural gas industry, which recognized exploration expenditures as they are incurred. This procedure is based on IFRS 6 "Exploration and Evaluation of Mineral Resources", which, despite not having an equivalent standard in Brazil, is being used to produce more reliable and more relevant financial statements, in accordance with CPC 23 - Accounting Policies, Changes in Estimates and Rectification of Errors. The adjustment was recognized retrospectively in the balance sheet on the transition date.' (Source: Company's Annual Report 2010 - footnote on page 27).

In 2011, two voluntary accounting changes were made. In this year, the firm reclassified R\$ 634.8 million (less than $5 \%$ of total assets) into accounts of current assets group; and performed a small assets write-down in the amount of R $\$ 40.4$ million. In this period the total consolidated net losses were R $\$ 509.9$ million.

The following information is taken from the Company's footnote. 
'2. Presentation of the Financial Statement

Preparation Basis

e. Reclassification

The Company reclassified, for a better presentation, of the balance sheet as of December 31, 2010 , the amount of R $\$ 634,799$ associated to the guarantees offered to ANP for the performance of the Minimum Working Program. The reclassification from "marketable securities" to "restricted deposits" (see note 7), both current assets, was made in the Quarterly Information (ITR) as of June 30, 2011. There was no change in the statement of operations, statement of comprehensive income, statement of change in shareholders' equity, statement of added value, neither in cash nor in cash equivalent balance in the cash flow statement.

The Company reclassified, for a better presentation, in the Statements of Cash Flow and Statement of Added Value of the parent company as at 31 December 2010, some R \$ 146,034 of expenses related to share-based plans from "administrative and general expenses" to the line "equity income (loss)". See note 3 (o). There was no change in the loss for the year, neither in the variation of cash nor cash equivalents previously presented in the individual financial statements of the parent company, and there was not any change in the consolidated financial statements.' (Source: Company's Annual Report 2011 - footnote on page 30).

In its growth stage (2008 to 2011), the company had the known incentives to perform opportunistic accounting choices, as predicted by the PAT hypothesis. Besides its significant importance in the Brazilian capital market, the company operated in a regulated environment, offered significant benefits to its managers, and also issued bonds with accounting covenants, however there was no evidence that the Company ever implemented any kind of opportunistic accounting changes. The observed accounting changes didn't produce any significant impact on the net income and did not affect the balance sheet structure substantially.

During its decline stage (2012 to 2015), we observed that the company had operational disappointments, faced serious financial problems and took a severe downturn in its stock prices.

In 2012, the Company issued new international bonds, changed its CEO, made a business combination (merger upstream), and also informed that the previous production estimates needed to be reduced. In this year, net losses had increased to 1.2 billion (against $\mathrm{R} \$ 509.9$ million in 2011). In 2013, the Company incurred in a debt covenant violation and filed for bankruptcy protection, besides changing the composition of its Board of Directors and selling relevant shareholding shares.

Although in 2012 and 2013 the company had a serious operational and financial difficulties, there was no evidence that it made any opportunistic accounting choice. In these years, the Company did make two important voluntary accounting changes, though.

In 2012, the firm reclassified retrospectively R $\$ 5.9$ billion of E\&P Assets from Intangible Assets to Fixed Assets into the 2011 financial statements. The Company justified the voluntary reclassification as a way to align its accounting practices with those most widely used by other companies in the oil and gas industry.

The following information was taken from the Company's footnote.

'In order to align its accounting practices with those most widely used by other companies in the O\&G industry, the Company reclassified in its Balance Sheet as of December 31, 2011 the amount of R \$ 5,916,928 associated with exploration CAPEX from intangible assets to E\&P fixed assets. The total balance, previously classified as intangible assets, in the amount of R $\$$ $7,408,651$, was not fully reclassified, except for the balance of $\mathrm{R} \$ 1,491,723$ associated with the subscription bonuses which, owing to their nature, remain recorded as intangible assets.

Moreover, the Company reclassified from fixed to intangible assets the balance of R\$ 21,001 , associated with the caption "Information processing systems and programs." These reclassifications do not alter total assets, liabilities or equity and also do not change retained earnings (deficit)'. 


\begin{tabular}{lcc}
\hline & $\begin{array}{c}\text { Intangible } \\
\text { assets }\end{array}$ & Fixed assets \\
\hline Balances previously as of December 31, 2011 & $7,408,651$ & 276,856 \\
E\&P fixed assets & $(5,916,928)$ & $5,916,928$ \\
Information processing systems and programs & 21,001 & $(21,001)$ \\
\cline { 2 - 3 } Balances as of December 31, 2011 after reclassification & $1,512,724$ & $6,172,783$ \\
\hline Source: Company's Annual Report 2012 - footnote on page 41. & &
\end{tabular}

In 2013, the company made a significant impairment provision of R $\$ 7.7$ billion of Fixed Assets and R\$ 1.0 billion of Intangible Assets. The accounting write-downs of exploratory drilling expenses recorded in fixed assets reflected the difficulties in its production process. In this year, the Company recorded a net loss of R\$17.4 billion. In this year, IFRS 5 (Non-Current Assets Held for Sale and Discontinued Operations, equivalent to CPC 31 issued by Brazilian Accounting Standard Board) also became an important accounting standard for the Company as it sold relevant fixed assets.

In this period, it seems that operational and financial difficulties were the only relevant factor for the presence of changes in accounting practices (reclassifications and assets write-downs). It is noteworthy that the assets write-downs depended on the Company's evaluation whether the assets could generate future economic benefits, as required by the Impairment Test.

At this point, it was important to ask whether the company could have made the write-down of assets in the previous year, i.e. whether the company intentionally delayed the asset write-down recognition from 2012 to 2013 or not. Despite the beginning of its operational problems in 2012, there is no evidence that the estimated production of oil and gas would not take place.

There were suspicions, however spread in Brazilian newspapers and magazines, about the company`s tendency to be too optimistic in its production estimates. Unfortunately, just when the production announcement was made, it was possible to confirm whether the initial estimates were appropriate or not. Notably, most part of the production announcements occurred in 2013. Table 2 shows the evolution of write-drowns of fixed and intangible assets in the years 2011 to 2013.

Table 2. Accounting Exploration and Production write-downs of fixed and intangible assets (R\$ in millions)

\begin{tabular}{|c|c|c|c|c|c|c|c|}
\hline \multirow[b]{2}{*}{ Year } & \multicolumn{3}{|c|}{ Write-down } & \multirow[b]{2}{*}{$\begin{array}{c}\text { Depreciation } \\
\text { or } \\
\text { Amortization }\end{array}$} & \multirow[b]{2}{*}{$\begin{array}{l}\text { Purchases } \\
\quad \text { (less } \\
\text { Disposals) }\end{array}$} & \multirow[b]{2}{*}{$\begin{array}{l}\text { Account } \\
\text { Variation }\end{array}$} & \multirow[b]{2}{*}{$\begin{array}{l}\text { Exploration } \\
\text { expenses } \\
\text { (Income } \\
\text { Statement) }\end{array}$} \\
\hline & $\begin{array}{c}\text { Dry wells, } \\
\text { subcommercial } \\
\text { areas and sunk } \\
\text { costs } \\
\text { (a) }\end{array}$ & $\begin{array}{l}\text { Impairment } \\
\text { Provision } \\
\text { (b) }\end{array}$ & $\begin{array}{c}\text { Total } \\
(\mathrm{a}+\mathrm{b})\end{array}$ & & & & \\
\hline \multicolumn{8}{|c|}{ Panel 1 - Fixed Assets } \\
\hline 2011 & $(236,055)$ & - & $(236,055)$ & - & $3,114,351$ & $2,878,296$ & \\
\hline 2012 & $(671,373)^{\mathrm{a}}$ & - & $(671,373)$ & $(43,341)$ & $4,370,326$ & $3,655,612$ & 871,523 \\
\hline 2013 & $(1,437,360)^{\mathrm{a}}$ & $(7,743,164)^{\mathrm{a}}$ & $(9,180,524)$ & $(110,927)$ & $2,716,942$ & $(6,574,509)$ & $1,514,312$ \\
\hline \multicolumn{8}{|c|}{ Panel 2 - Intangible Assets } \\
\hline 2011 & - & - & - & - & 555,575 & 555,575 & - \\
\hline 2012 & $(20,100)$ & - & $(20,100)$ & $(6,491)$ & 575,375 & 549,084 & $(20,100)$ \\
\hline 2013 & $(403,134)^{\mathrm{c}}$ & $(1,013,106)^{b}$ & $(1,416,240)$ & $(685)$ & 93.141 & $1,323,784$ & $(403,134)$ \\
\hline
\end{tabular}

Source: : Information available in the Company's Annual Reports - Footnotes of fixed and intangible assets.

Note: (a) Write-downs of Campos, Pará-Maranhão, Santos, Espírito Santo, Paraíba, and Colombia basins. (b) sub-commercial areas of BMC41 Block, Tupungato and Tambora accumulations, and BM-S-37, Bm-C-39, BM-C-40, BM-C-41, BM-C-42, BM-S-56, BM-S-58 and BMS-59 Blocks. (c) Total impairment of Tubarão Azul, Areia, Gato e Tigre Basins; total impairment of Itacoatiara, Viedma, Tulum e Vesuvio areas in Campos Basins; and partial impairment of Tubarão Martelo of Campos Basins.

Finally, in the years 2014 and 2015, the Company`s last stage of its business life cycle, we still could not find any voluntary accounting change disclosed in the financial statements. It is important to emphasize that these years were also very problematic for the company, as it had to take a large loan-bridge and also hold selling its assets to honor its obligations. After a great deal of effort, in 2014, the company finally got the approval for its bankruptcy protection, but bankruptcy was already inevitable. 
Overall, the evidence presented in this case study shows that there is no evidence that the Company made opportunistic increasing-income (or decreasing-income) accounting changes to impact their financial debtcovenants and bonus plan (to reduce the probability of government intervention) during the growth and decline stages of its business live cycle.

There is no evidence of the Company's making accounting changes to avoid new regulations or other forms of interventions (tax increasing, for example) arising from the political costs due to its main activity (oil and gas exploration) being regulated by the government (ANP Agency). In almost every analyzed Income Statements, the Company showed Net Losses and did not need perform income-decreasing accounting changes (Political Costs Hypothesis).

Although voluntary accounting changes are not a usual practice (Nobes and Stadler, 2014), the Company made only four visible accounting changes in a nine year-period. They were the early adoption of a mandatory standard (2010), two reclassifications of assets accounts (2011 and 2012), and one significant asset write-down (2013). While the asset write-down could be explained by the operational problems (which caused a significant negative effect on Income Statement), the other changes could be associated with some improvements in the financial statements reports. Naturally, the classification accounting change could be simpler and less costly to apply in comparison to recognition and measurement accounting changes.

In short, the four main changes of accounting practices performed during the growth and decline periods of the Company's business life cycle did not seem motivated by an opportunistic action, as suggested by the PAT hypothesis (opportunistic approach).

To understand why the PAT (opportunistic approach) does not help to explain the accounting choices in this case, we provided an alternative explanation, based on three different particular aspects that helps to justify our results and show why this case is not just an anomaly (Banber, Christensen and Gaver, 2000) which allows us to understand why most Brazilian companies prefer to perform only efficient accounting changes when a change is necessary.

First, Brazilian companies are characterized as companies with concentrated systems of corporate governance, where a few shareholders hold a control block of shares of the companies (concentrated ownership systems), as suggested by Theory of Corporate Scandals, proposed by Coffee Jr. (2005).

As companies in Europe, the examined company was characterized as a company with concentrated governance systems, where a single shareholder held the controlling block of shares of the company. The controller shareholder was the Chairman of Board of Directors and the CEO of the Company, as it is common in family businesses. Thus, the controller shareholder could keep a closer look at management curbing any self-serving action on their part as well as defining the best company's accounting practices for external users (banks and small investors). In 2010, the controlling shareholder held $61.3 \%$ of the company's shares. This ownership interest was reduced to $50.15 \%$ after selling some stock in 2013 . The participation in the equity of the company was reduced to 11.14\% in March 2013 and sold 5.49\% and 1.54\% of the shares in September 2013 and August 2013, respectively.

Second, consistently with the statement that the largest companies (size effects) receive more attention from the government, analysts and gatekeepers, the analyzed Company was the largest private oil and gas explorer in Brazil and also had a significant participation in the Brazilian stock market. In December 2013, the company had $4.52 \%$ in the Ibovespa index. In its best days, on the 15th of October 2010, OGX shares were as high as R\$23.27 (a market price close to the biggest oil company in Brazil - Petrobras). This company was getting a lot of attention, and maybe for this reason, it may have avoided performing opportunistic accounting choices.

In short, Bos and Donker (2004) suggest that institutional monitoring, like external control from large shareholders, institutional shareholders, financial authorities, and internal control from supervisory boards are important to reduce the agency problems and avoid opportunistic accounting choices.

Finally, the results could be explained by a potential damage in the Company's image, according the Corporate Reputation Hypothesis. It is common for large companies to want to project a good image and improve their reputation, and if they engaged into making opportunistic accounting changes, it could reflect negatively as there is a considerable degree of institutional monitoring on them.

Besides, an excellent relationship with top representatives of the federal and local governments could improve the controller shareholders ' image of a successful businessman, with great capacity to obtain good results. In addition, the top executive group (called 'Dream Team') was formed by highly qualified professionals coming from the main competitor (Petrobras). 
This positive image and reputation helped the managers to do good business during the growth phase of the company and inspired peace for a company operating in such a risky sector. On the other hand, during the decline phase, in addition to the operational problems, the distrust towards the top executives 'ability was very high and caused a significant drop in the company's stock prices.

These alternative explanations are consistent with the efficient approach for the PAT hypothesis, which suggest that managers will use the accounting system flexibility to provide better financial statements during the business life cycle, although the voluntary accounting changes don't represent the norm (Nobes and Stadler, 2014). Our study also suggests that the efficient approach of the PAT hypothesis can be useful to explain the accounting choices made by big Brazilian companies, particularly outside the USA context (Europe and South America), because they have different external incentives that can be explained by the Theory of Corporate Scandals; the Monitoring Hypothesis and the Corporate Reputation Hypothesis.

\section{CONCLUSIONS}

Analyzing company risk is a challenge for stakeholders, especially when operations are off-balance sheet. To identiThis survey examined the major accounting changes made by OGX managers and accountants throughout their life cycle. The analysis of this critical case study showed that, although the comoany's managers and accontants had the incentives to perform accounting choices like the ones predicted by the PAT hypothesis, there was no evidence of their ever making opportunistic increasing-income accounting changes to impact their financial debt-covenants and bonus plan, or decreasing-income accounting to avoid government intervention.

Overall, the results demonstrate that the company made four voluntary accounting practice changes, which were related to recognition and classification of its assets, during its nine years of existence. The voluntary accounting practices changes were: (a) the earlier IFRS 6 adoption (in 2010); (b) voluntary assets reclassification (in 2011 and 2012); and (c) voluntary recognition of assets write-downs (in 2013). None of these accounting changes seemed to have been opportunistic or created any relevant contract, for the benefit for the Company or the managers.

Since the opportunistic approach of PAT does not seem to explain the accounting choices made in this critical case study, it seems appropriate to use the Theories of Corporate Scandals, Monitoring Hypothesis and Corporate Reputation Hypothesis identified in the construction of the theoretical background of this research.

The capital of Brazilian listed companies is usually concentrated in the hands of a small number of shareholders who participate in the management of these companies. Therefore, as proposed by Coffee $\operatorname{Jr}(2005)$, there are no incentives for managers and accountants to peform earnings management. OGX had obtained funds through loans from Brazilian Government agencies with qualified analysts who closely monitor the performance of borrowers. And lastly, OGX, like all other companies in Group X, had always valued maintaining a prominent reputation on the national and international scene.

It is important to highlight that despite the flexibility of the accounting standards, the managers and accountants of OGX did not seem to have made opportunistic accounting changes, despite incentives to do so. They preferred instead, to disclosure unlawfully overoptimistic operational information in general reports to the market rather than make any accounting manipulations in annual reports, as predicted by the Opportunistic PAT Hypothesis.

The aggressive dissemination of good operational information used by the company's controller, including violating rules of the financial market, resulted in penalties imposed by the Brazilian securities exchange commission. Notably, our analysis shows that the company did have problems, but they were not in its accounting practices. Consequently, the idea that brazillian managers frequently use accounting improperly implies a very limited view.

Our study extends the literature in three ways. First, it show different explanations for companies not to perform opportunistic accounting choices in specific contexts, even when there are incentives to do so asthe concentrated or dispersed ownership systems (Theory of Corporate Scandals), the level monitoring of institutional entities (Monitoring Hypothesis) and the reputation concern (Corporate Reputation Hypothesis) may be important factors to consider in future empirical studies.

Second, we provide more insights using a holistic view by conducting a qualitative multi-period and multi-incentives analysis instead of selecting just specific events and specific accruals metrics. The analysis of the company's business life cycle (growth or decline) and the companies' operating characteristics are relevant to understanding why they carry out changes in their accounting practices. 
Finally, our study suggests that researchers should consider the Brazilian institutional scenario and the incentives it offers for the accounting choices before deciding to replicate research done abroad. As noted earlier, reputable researchers have criticized the weaknesses of the models used to estimate earnings management, and without proper care, there is always the possibility of attribution errors.

Inequivocably, we were lucky to have an opportunity to conduct a qualitative longitudinal study to help us understand the phenomenon of voluntary accounting change so that our results can benefit the develpment of future empirical tests and refine the hypothesis usually tested in Brazilian scenarios.

\section{REFERENCES}

Armenic, J. A. (1992). Case study in corporate financial reporting: Massey-Ferguson's visible accounting decisions 1970-1987. Critical Perspectives on Accounting, 3, 1-43. DOI: https://doi.org/10.1016/10452354(92)90013-H.

Ball, R. (2013). Accounting Informs Investors and Earnings Management is Rife: Two Questionable Beliefs. Accounting Horizons, 27(4), 847-853. DOI: http://dx.doi.org/10.2139/ssrn.2211288.

Bos, A. de, Donker, H. (2004) Monitoring accounting changes: empirical evidence from the Netherlands. Corporate Governance, 1(1), 60-73. DOI: https://doi.org/10.1111/j.1467-8683.2004.00343.x.

Chen, K. C.W., Lee, C. J. (1995). Executive bonus plans and accounting trade-offs: The case of oil and gas industry, 1985-86. The Accounting Review, 70(1), 91-111.

Christie, A. A., Zimmerman, J. L. (1994). Efficient and opportunistic choices of accounting procedures: corporate control contests. The Accounting Review, 69(4), 539-566.

Chun, R. (2005). Corporate reputation: meaning and measurement. International Journal of Management Reviews, 7(2), 91-109. DOI: https://doi.org/10.1111/j.1468-2370.2005.00109.x.

Cooper, D. J., Morgan, W. (2008). Case study research in accounting. Accounting Horizons, 22(2),159-178. DOI: https://doi.org/10.2308/acch.2008.22.2.159.

Coffee Jr., J. C. (2005). A theory of corporate scandals: Why the USA and Europe differ. Oxford Review of Economic Policy, 21(2), 198-211. DOI: https://doi.org/10.1093/oxrep/gri012.

Dechow, P.; Skinner, D. (2000). Earnings management: reconciling the views of accounting academics, practitioners and regulators. Accounting Horizons, 14(2), 235-250. DOI: https://doi.org/10.2308/acch.2000.14.2.235.

Eisenhardt, K. M (1989). Building theories from case study Research. The Academy of Management Review, 14(4), 532-550. DOI: https://doi.org/10.2307/258557.

Fern, R. H., Brown, B. C., Dickey, S. W. (1994). An empirical test of politically-motivated income smoothing in the oil refining industry. Journal of Applied Business Research, 10(1), 92-100. DOI: https://doi.org/10.19030/ jabr.v10i1.5967.

Fields, T. D., Lys, T. Z., Vicent, L. (2001). Empirical research on accounting choice. Journal of Accounting and Economics, 31, 255-307. DOI: https://doi.org/10.1016/S0165-4101(01)00028-3.

Hall, S., Stammerjohan, W. W. (1997). Damage awards and earnings management in the oil industry. The Accounting Review, 72(1), 47-65.

Han, J. C. Y., Wang, S. (1998). Political costs and earnings management of oil companies during the 1990 Persian Gulf crisis. The Accounting Review, 73(1), 103-117.

Hendriksen, E. S, Van Breda, M. E. (1991). Accounting Theory. 5th Edition, Irwin, Homewwod, IL.

Jeanjean, T.; Stolowy, H. (2008). Do accounting standards matter? An exploratory analysis of earning management before and after IFRS adoption. Journal of Accounting and Public Policy, 27(6), 480-494. DOI: https://doi. org/10.1016/j.jaccpubpol.2008.09.008.

Johnson, W. B., Ramanan, R. (1988). Discretionary accounting changes from "Successful Efforts" to "Full Cost" Methods: 1970-76. The Accounting Review, 63(1), 96-110.

Jorissen, A.; Otley, D. (2010). The management of accounting numbers: case study evidence from the 'crash' of an airline. Accounting and business Research, 40(1), 3-38. DOI: https://doi.org/10.1080/00014788.2010.96 63382 . 
Malmquist, D. H. (1990). Efficient contracting and the choice of accounting method in the oil and gas industry. Journal of Accounting and Economics, 12(1), 173-205. DOI: https://doi.org/10.1016/0165-4101(90)90046-7

Nobes, C. W., Stadler, C. (2014). The qualitative characteristics of financial information, and managers' accounting decisions: evidence from IFRS policy changes. Social Science Research Network (http://ssrn. com/abstract $=2598171)$.

Pincus, M.; Rajgopal, S. (2002). The interaction between accrual management and hedging: Evidence from oil and gas firms. The Accounting Review, 77 (1): 127-160.

Riahi-Belkaoui, A. (2004). Accounting Theory. 5th Edition, South-Western Cengage Learning, London.

Robert, P. W.; Dowling, G. R. (2002). Corporate reputation and sustained superior financial performance. Strategic Management Journal, 23, 1077-1093. DOI: https://doi.org/10.1002/smj.274.

Ronen, J., Yaari, V. (2010). Earnings management: emerging insights in theory, practice, and research. Springer Series in Accounting Scholarship. Springer Science. New York.

Ryan, R., Scapens, R. W., Theobald, M. (2002) Research method and methodology in finance and accounting. 2nd Edition, Thomson, London.

Scott, W. R. (2009). Financial Accounting Theory. 5th Edition, Pearson Prentice Hall, Ontario.

Stolowy, H., Breton, G. (2003) Accounts manipulation: A literature review and proposed conceptual framework. Working Paper. January, 2003.

Sunder, S. (1997) Theory of Accounting and Control. South-Western Publishing, Ohio.

Taleb, N. N. (2007). The Black Swan: Second Edition: The Impact of the Highly Improbable. Random House Trade. Paperback Edition. New York.

Watts, R. L., Zimmerman, J. L. (1986). Positive Accounting Theory. Prentice-Hall, New Jersey.

Watts, R. L. Zimmerman, J. L. (1990). Positive Accounting Theory: a ten year perspective. The Accounting Review $65,131-156$.

\section{How to cite this article}

Silva, A. H. C e, Sancovschi, M., \& Santos, A. G. C. dos. (2019). The opportunistic approach of the Positive Accounting Theory (PAT) fails to explain choices made at OGX: An anomalous situation? Revista de Contabilidade e Organizações, 13:e164412. DOI: http://dx.doi.org/10.11606/issn.1982-6486. rco.2019.164412 


\section{APPENDIX}

Table 1. Main Company’s Accounting Policy in 2012

\begin{tabular}{ll}
\hline \multicolumn{1}{c}{ Accounting Item } & \multicolumn{1}{c}{ Accounting Policy } \\
\hline Inventories & \\
\hline Crude oil produced or acquired & $\begin{array}{l}\text { Cost of production and adjusted to their realizable amounts. } \\
\text { The average cost to calculate the cost of products sold. } \\
\text { Cost of acquisition or production and adjusted to their } \\
\text { Materials and supplies }\end{array}$ \\
\hline Fixed assets &
\end{tabular}

\section{Fixed assets}

Cost adjusted to their recoverable value:

- Expenditures on exploration and development recorded under the successful efforts method.

Expenditures on well drilling and completion, support vessels and $\mathrm{E} \& \mathrm{P}$ equipment

- Expenditures of dry wells are to be recorded in results.

Costs of geological, geophysical and seismic surveys should be considered as expenses for the period when incurred. Depreciation Method: depreciated as from the declaration of com-merciality and commencement of production under the units of production method.

Machinery and equipment and other tangible assets used for administrative purposes

Cost adjusted to their recoverable value.

Depreciation Method: depreciated under the straight-line method.

\section{Intangible assets}

Bonuses paid to obtain concessions to engage in oil and natural gas E\&P activities

Cost of acquisition thereof, adjusted to their recoverable value.

Amortization Method: amortized as from the declaration of com-merciality and commencement of production under the units of production method.

Cost of acquisition.

Information processing systems and programs

Amortization Method: amortized under the straight-line method.

Impairment test
All assets according the accounting rule

Management conducts specific tests to analyze indications of im-pairment each year.

\section{Provisions}

Provision for asset retirement obligation (ARO)

Prior the declaration of commerciality: No provision is set up.

Development phase: an ARO provision is set up with a contra entry under fixed assets.

\begin{tabular}{ll}
\hline Financial Debts & $\begin{array}{l}\text { Capitalized (interest and exchange variation) for qualified } \\
\text { assets }\end{array}$ \\
\hline Borrowing costs & $\begin{array}{l}\text { Expenditures already incurred by the joint ventures, } \\
\text { regardless of whether or not they are billed by the suppliers }\end{array}$ \\
\hline Recognition of sales and costs of oil and gas produced & \\
\hline Prior to declaration of commerciality (exploration phase) & $\begin{array}{l}\text { Net of the respective production costs, as recovery of the } \\
\text { costs capitalized in such assets (reduction of the capitalized } \\
\text { costs) } \\
\text { Recognized in the income statement. }\end{array}$ \\
\hline
\end{tabular}

Source: Company's Annual Report 2012, footnotes on pages 45 to 65 . 
Table 2. Basic accounting information of the Company

\begin{tabular}{|c|c|c|c|c|c|c|c|c|c|}
\hline \multicolumn{10}{|c|}{ Panel 1 - Evolution of the Company's key financial metrics (R\$ in thousands) } \\
\hline & 2006 (b) & 2007 (b) & 2008 & 2009 & 2010 & 2011 & 2012 & 2013 & $2014^{1}$ \\
\hline Total Assets & 3 & $4,371,512$ & $9,747,932$ & $10,388,632$ & $9,988,534$ & $14,350,197$ & $17,116,348$ & $5,389.639$ & 128,302 \\
\hline \multicolumn{10}{|l|}{ Noncurrent Assets } \\
\hline Fixed Assets & - & 7,581 & 12,066 & 19,917 & 27,624 & 276,856 & $10,027,389$ & $3,351,878$ & - \\
\hline Deferred Assets & - & 9,647 & - & - & - & - & - & - & - \\
\hline Intangible Assets & - & $2,015,565$ & $2,037,604$ & $2,718,091$ & $4,589,418$ & $7,408,651$ & $2,060,438$ & 730,268 & - \\
\hline Total Liabilities & 948 & $2,059,194$ & 582,203 & 582,203 & 748,736 & $5,481,164$ & $9,385,272$ & $15,123,999$ & 109,768 \\
\hline Shareholders' Equity & $(945)$ & $2,312,318$ & $9,165,729$ & $9,186,290$ & $9,239,798$ & $8,869,033$ & $7,731,076$ & $(9,734,360)$ & 18,534 \\
\hline Net Income or (loss) & $(5,506)$ & $(6,353)$ & 359,884 & 10,829 & $(135,525)$ & $(509,885)$ & $(1,172,774)$ & $(17,434,691)$ & $9,868,021(4)$ \\
\hline EBITDA & NI & NI & NI & NI & NI & $(430,508)$ & $(343,322)$ & $(33,913)$ & $(16,097)$ \\
\hline EBIT & NI & NI & NI & NI & NI & $(733,994)$ & $(1.133,156)$ & $(33,913)$ & $(5,548)$ \\
\hline Paid Dividends & - & - & - & - & - & - & - & - & - \\
\hline Auditor & Acal & KPMG & KPMG & KPMG & KPMG & $E \& Y$ & E\&Y & $E \& Y$ & $\mathrm{PwC}$ \\
\hline \multicolumn{10}{|c|}{ Panel 2 - Date of the financial statements filed in the CVM website } \\
\hline Event Type & 2006 & 2007 & 2008 & 2009 & 2010 & 2011 & 2012 & 2013 & 2014 \\
\hline Filing in CVM & (a) & (a) & $3 / 25 / 09$ & (a) & $3 / 25 / 11$ & $3 / 22 / 12$ & $3 / 26 / 13$ & $4 / 01 / 14$ & $3 / 23 / 2015$ \\
\hline Voluntary Restatement & $3 / 30 / 07$ & $3 / 31 / 08$ & - & $4 / 20 / 10$ & - & $3 / 23 / 12$ & - & - & - \\
\hline Mandatory Restatement & - & - & - & - & $2 / 27 / 12$ & - & - & - & - \\
\hline
\end{tabular}

Source: Original Consolidated Financial Statements data of the Company available on the CVM's website on August 5, 2015. (a) Information available on the CVM website. (b) By the year 2008 the Financial Statements (DFP) published followed the local GAAP like applicable corporate law.

Note: The consolidated financial statements were being presented in thousands of Brazilian Reais (R\$), which is the Company's functional currency. NI - Not Informed. In 2014 the net income (losses) were R $\$ 9,884,526$ from discontinued operations and (R\$16,505) from continued operations.(1) Deconsolidation of OGX P\&G: in September of 2014, after extinction of the debt through issue of equity instruments, Company lost the control that it previously had over investee OGX P\&G, with its equity interest dropping from $99.99 \%$ to $28.57 \%$. The income statement and balance sheet accounts of OGX P\&G are no longer consolidated by OGPar and were presented as discontinued operations. 